\title{
Potentially Toxic Metal and Metalloid Fractionation Contamination in Sediments of Daya Bay, South China Sea
}

DOI: $10.15255 /$ KUI.2014.037

KUI-15/2015

Original scientific paper

Received December 26, 2014

Accepted April 13, 2015

\author{
L. L. Cao, ${ }^{a^{* *}}$ J. Yang, ${ }^{\mathrm{b}^{* *}}$ P. Wang, $\mathrm{a}^{*}$ L. Wang, ${ }^{\mathrm{b}^{*}}$ \\ H. T. Tian, ${ }^{\mathrm{a}}$ M. K. Zou, and J. Xie \\ a South China Sea Marine Engineering and Environment \\ Institute, SOA, 510300 Guangzhou Guangdong, PR China \\ b South China Sea Marine Environment Monitoring Center, SOA, \\ 510915 Guangzhou Guangdong, PR China \\ Shanwei Marine Environment Monitoring Center Station, SOA, \\ 516600 Shanwei Guangdong, PR China
}

\begin{abstract}
$\|$ Abstract
The metal profiles in sediments of the Daya Bay (DYB) in China were established using sequential extraction protocols proposed by the European Community Bureau of Reference (BCR). The surface sediment samples from 23 representative stations were collected in 2011 and were analysed to evaluate the mobility and bioavailability of a suite of potentially toxic metals $(\mathrm{Cr}, \mathrm{Cu}, \mathrm{Ni}, \mathrm{Zn}, \mathrm{Pb}$ and $\mathrm{Cd})$ and metalloid $(\mathrm{As})$. The obtained ranking order of migration and transformation, and the degree of pollution was $\mathrm{Pb}>\mathrm{Cd}>\mathrm{Cu}>\mathrm{Zn}>\mathrm{Ni}>\mathrm{Cr}>\mathrm{As}$. Among these elements, $\mathrm{Pb}$ is considered to pose a serious threat to human health and ecological environment due to its significant percentage in non-residual form. The ratios of secondary and primary phases showed that studied sediments are moderately to heavily polluted with $\mathrm{Cu}$ and $\mathrm{Zn}$, and $\mathrm{Cd}$ and $\mathrm{Pb}$ respectively. The levels of association between the variables (metal-metalloid) at each step of sequential extractions were evaluated with multivariate statistical analysis, including correlation analysis and principal components analysis. With these analyses, the possible sources of potential pollution were deduced. The correlation analysis revealed that Total Organic Carbon content is the most important influencing factor affecting the distribution of potentially toxic elements in Daya Bay. The principal components analysis (PCA) suggested that the studied elements in DYB area originate primarily from natural weathering and secondly from industrial wastewater and aquaculture waste water.
\end{abstract}

$\|$ Keywords

Toxic elements, metal fractionation, sequential extraction, risk assessment, sediment, Daya Bay

\section{Introduction}

The pollution of the natural environment by heavy metals is recently a topic of much discussion; and the issue of potentially toxic metal pollution in coastal marine sediments has received much more attention from researchers over the past few decades. Due to dense anthropogenic activities as well as increasing usage of industrial products, a huge amount of waste products is discharged into water bodies without proper treatment. Coastal marine sediments not only function as a reservoir for metals, but also as a natural and pollution source of metals. ${ }^{1}$ These in particular have drawn much attention due to their biological accumulation, toxicity and persistence once the concentrations surpass certain thresholds in the sediments, resulting in potential long-term exposure of humans and organisms to these metals. The mobility and toxicity of metals associated with sediments are generally affected by metal speciation and sediment composition. ${ }^{2}$

Although a number of dredging and remediation actions

\footnotetext{
*Corresponding author 1: Dr. Ping Wang, e-mail: pwangsoa@163.com Corresponding author 2: Dr. Liang Wang, e-mail: wwldxh@163.com ${ }^{* *}$ Equal contribution
}

are focused on metals, successful projects rely on the good understanding of the behaviour of contaminants when bottom sediments are dredged, brought to the surface and exposed to different environmental conditions. Total metal concentrations can be used as an indicator for environmental assessment, however they cannot be used to assess bioavailability and the environmental/human health risks. ${ }^{3}$ The risks posed by hazardous substances in dredged sediments are determined by their "mobile" and "available" concentrations. ${ }^{4}$ Thus, other than measurement of total concentrations of metals in sediments, determination of their geochemical fractionation is also very important for assessing their mobility, bioavailability and potential toxicity.

Our main objectives were (a) to assess the concentration and speciation of toxic metals in the sediments of the Daya Bay, and (b) to carry out a preliminary evaluation of the potential environmental risks. The results from this study will provide a better understanding of the risks of metals in the sediments of the studied region.

Daya Bay, located in the northeast part of the South China Sea, has become a vital economy development zone. It is composed of a series of sub-basins, including Dap- 


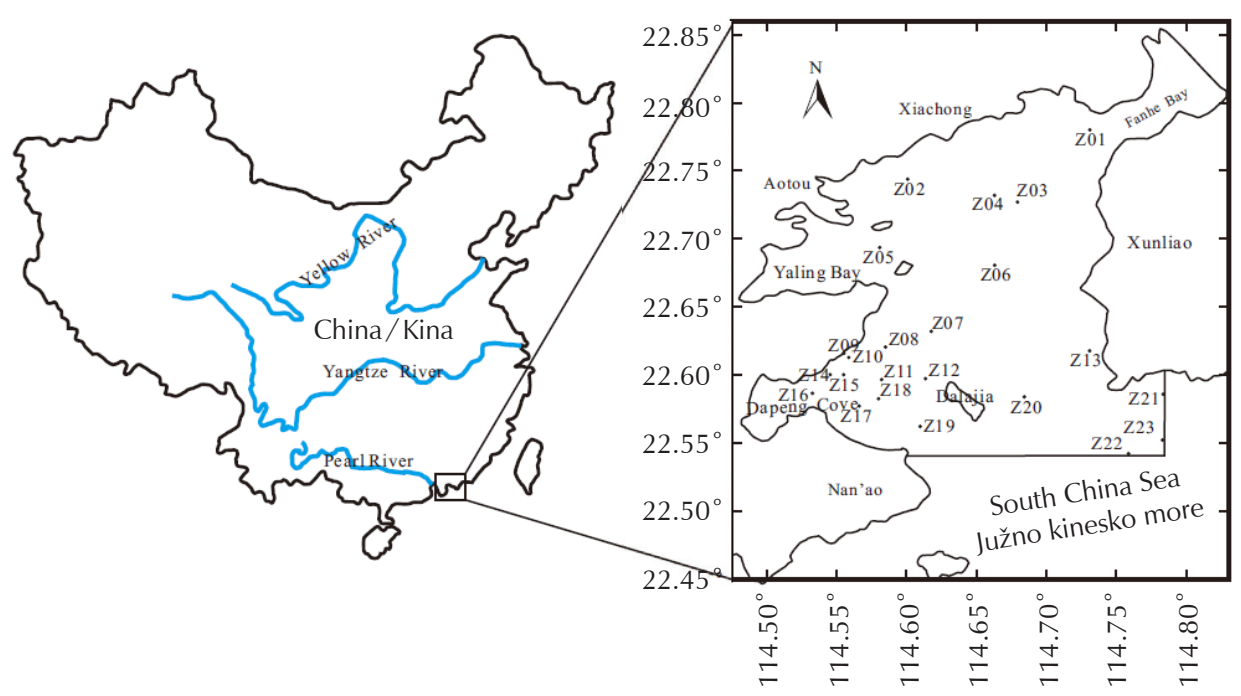

Fig. 1 - Sampling stations in studied regions

Slika 1 - Lokacije na kojima su uzimani uzorci

eng Cove, Fanhe Bay and Yaling Bay. Since the 1980s, the population number as well as aquacultural and industrial pollution along the coastline and harbours have increased dramatically. 5,6 In this region, the distribution of metals and their speciation in different fractions in the sediments have not been fully studied so far, and comprehensive multi-factor characteristics analyses should be conducted.

\section{Materials and methodology}

\section{Sampling and sediment pretreatment}

The surface sediments samples were taken around the Daya Bay from May to June in 2011, and collected in brown glass bottles and polyethylene bags, and stored at low temperature $\left(-20{ }^{\circ} \mathrm{C}\right)$ for further experiments. The sampling stations are shown in Fig. 1. The concentrations of $\mathrm{Cr}, \mathrm{Cu}, \mathrm{Ni}, \mathrm{Zn}, \mathrm{Pb}, \mathrm{As}$ and $\mathrm{Cd}$ were measured in the laboratory using standard methods.

\section{Analysis}

\section{Total concentrations}

The total concentrations of $\mathrm{Cr}, \mathrm{Ni}, \mathrm{Cu}, \mathrm{Pb}, \mathrm{Zn}, \mathrm{Cd}$ and $\mathrm{As}$ were detected by inductively coupled plasma-mass spectrometry (ICP-MS).

\section{Morphological analysis}

The modified European Community Bureau of Reference (BCR) sequential extractions method was used to analyse the speciation of heavy metals in this paper. ${ }^{7,8}$ The blanks were analysed the same time.

Step 1, Fraction 1 (F1, acid soluble fraction)

Subsamples (0.5 g) of dry sediment and $30 \mathrm{ml}$ of acetic acid were added to a $50 \mathrm{ml}$ Pyrex tube. The tubes containing the mixtures were shaken for 20 hours at room temperature $\left(22 \pm 2{ }^{\circ} \mathrm{C}\right)$ and extracts were separated from the residues by centrifugation at $3500 \mathrm{rpm}$. The supernatants were removed and the residues washed with $10 \mathrm{ml}$ distilled $\mathrm{H}_{2} \mathrm{O}$, shaken for an additional 10 minutes and centrifuged for 20 minutes at $3500 \mathrm{rpm}$. The supernatants were removed carefully and completely without loss of residues.

\section{Step 2 Fraction 2 (F2, reducible fraction)}

The residues from Step 1 were re-suspended by adding $20 \mathrm{ml}$ of $0.1 \mathrm{moll}^{-1} \mathrm{NH}_{2} \mathrm{OHHCl}(\mathrm{pH}=2.0)$ and the extraction was carried out as described in Step 1.

\section{Step 3 Fraction 3 (F3, oxidizable fraction)}

$20 \mathrm{ml}$ of $8.8 \mathrm{moll}^{-1} \mathrm{H}_{2} \mathrm{O}_{2}(\mathrm{pH} 2.0$ - 3.0) were added dropby-drop to the residues from Step 2 . The tubes were sealed with caps and the residues sequentially digested for 2 hours at room temperature and 1 hour at $85^{\circ} \mathrm{C}$ in a water bath. The digestion mixtures were concentrated by evaporation to the final volumes of $2-3 \mathrm{ml}$. Step 3 was repeated twice and $25 \mathrm{ml}$ of $1 \mathrm{moll}^{-1} \mathrm{NH}_{4} \mathrm{C}_{2} \mathrm{H}_{3} \mathrm{O}_{2}(\mathrm{pH}=2.0)$ was added to the cool residues, which were separated and rinsed as described in Step 1.

\section{Step 4 Fraction 4 (F4, residual fraction)}

The residues in Step 3 were transformed to a polytetrafluoroethylene beaker and $25.00 \mathrm{ml}$ nitrate, $2.00 \mathrm{ml}$ hydrofluoric acid and $2.00 \mathrm{ml}$ perchloric acid were added and digestion was carried out until the residues were almost dry. Residues were re-dissolved in nitrate $(1 \%)$, and prepared for further measurement. The metal concentrations in the extracts obtained at each step were determined using an atomic absorption spectrophotometer.

\section{Particle size and total organic carbon}

The analysis of granularity and Total Organic Carbon (TOC) were performed according to the specifications for marine monitoring (GB17378-2007). 


\section{Quality control}

Quality control was assured in the same way as the analysis of a marine sediment reference material (Offshore Marine Sediment, GBW 07314) with both duplicate and parallel samples. The duplicates showed a difference of $<10 \%$, while the spiked additions (blanks and samples) gave recovery percentages ranging from $95 \%$ to $106 \%$.
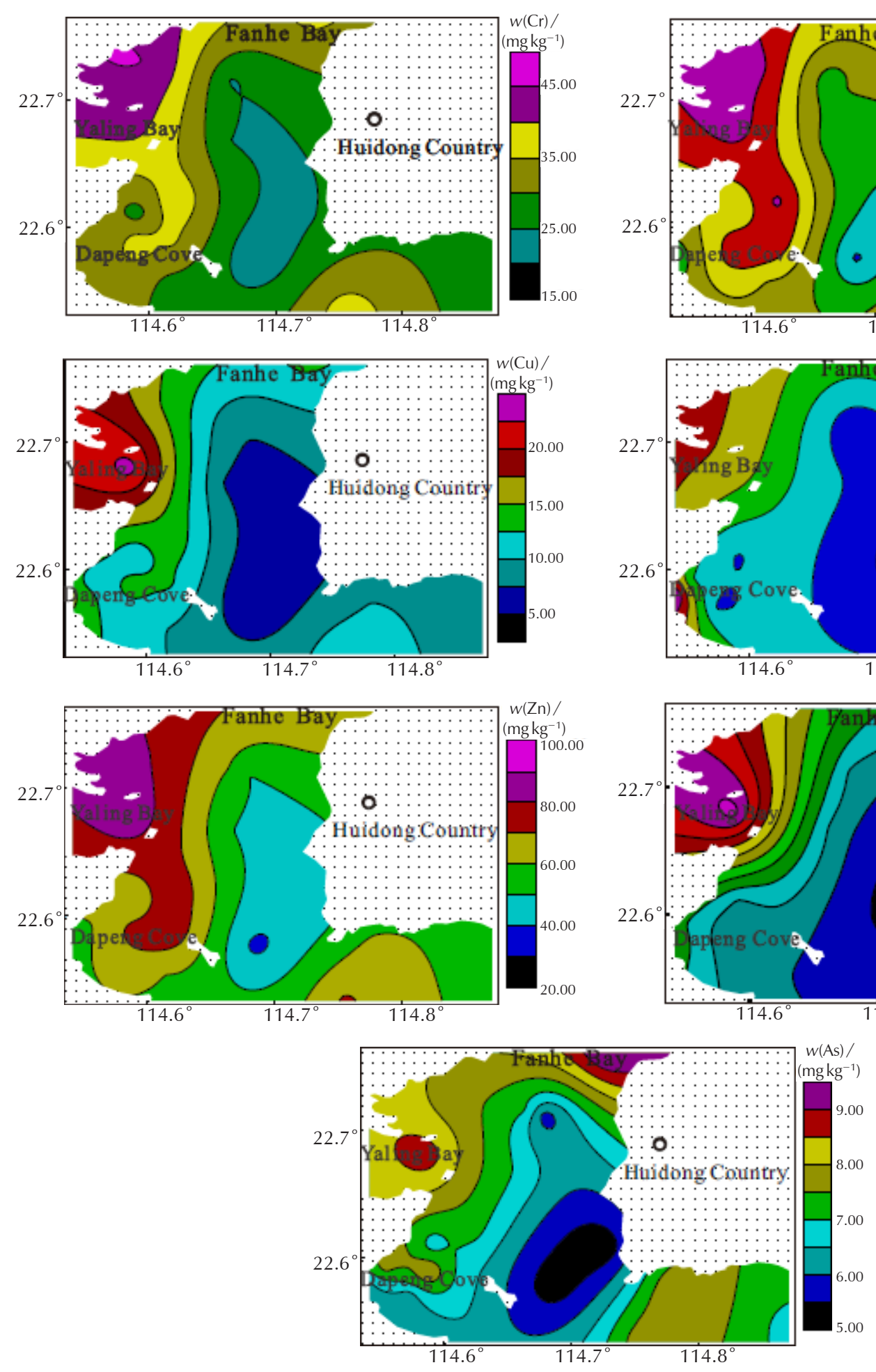

Fig. 2 - Spatial distribution of selected elements concentrations in surface sediments

Slika 2 - Prostorne varijacije koncentracija odabranih elemenata u površinskom sedimentu

\section{Results}

\section{Distribution of total metals}

According to Shepard's sediment granularity classification, ${ }^{9}$ the average clay, silt and sand contents in all samples are $4.9 \%, 77.0 \%$ and $18.1 \%$, respectively. The average percentages of clayey silt and sandy silt in silt samples are
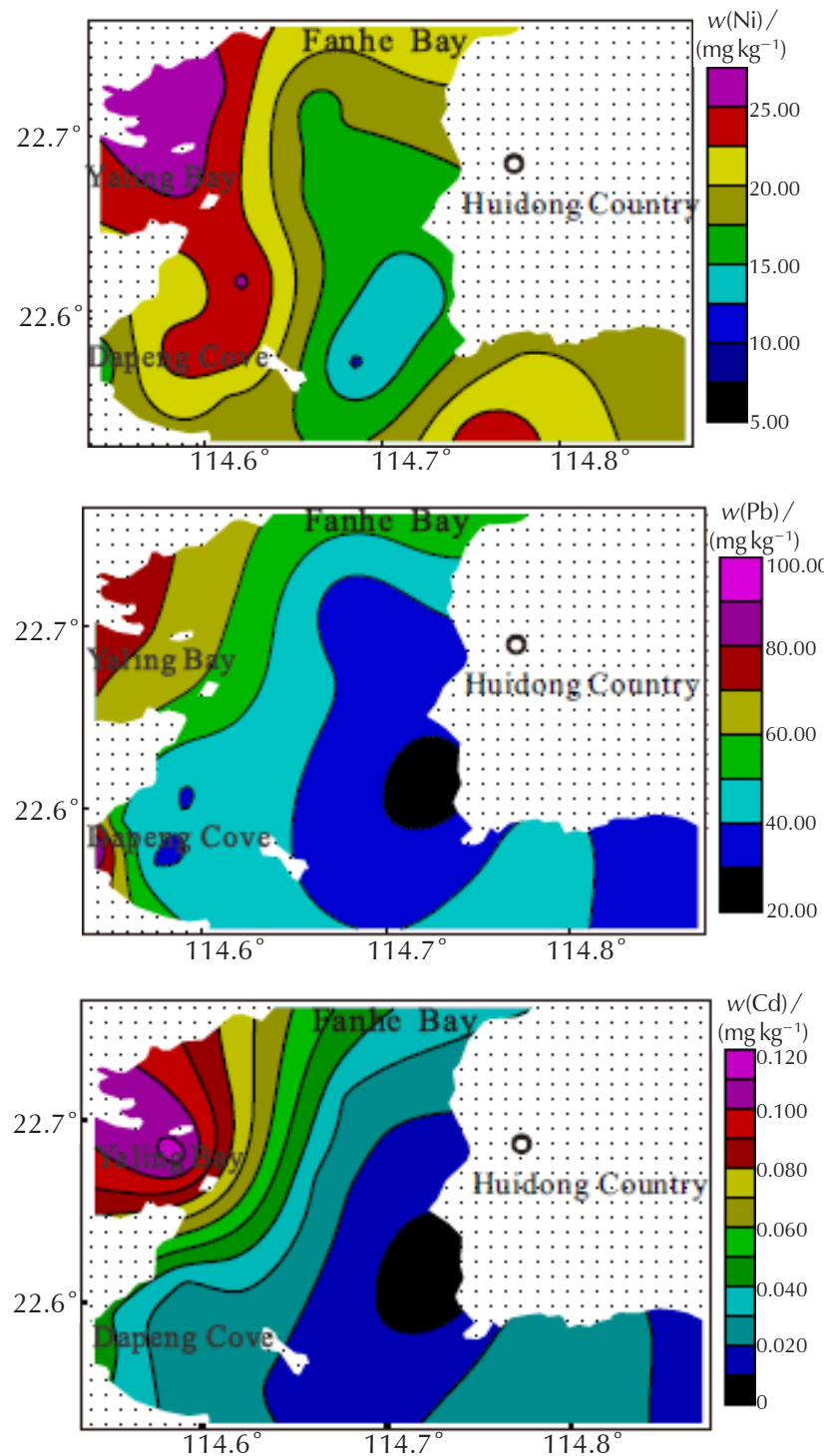

14.7 14.8 
$70.2 \%$ and $11.3 \%$, respectively. Of all the sampled sediments, only Z07 and Z11 near Dapeng Cove were sandy silt, Z13 was medium sand. Overall, the distribution of granularity in Daya Bay was more uniform.

The distribution of the selected elements in the studied region displayed large spatial variations (Fig. 2), and showed a ring shape and descending trend from the shore to the bay by varying degrees in accordance with the results of previous studies. ${ }^{10}$ The relatively high content of $\mathrm{Ni}, \mathrm{Cu}$, $\mathrm{Pb}, \mathrm{Zn}, \mathrm{Cd}$ and As occurred in the Dapeng Cove, Fanhe Bay and Yaling Bay. The highest values for $\mathrm{Cu}, \mathrm{Pb}, \mathrm{Zn}$, $\mathrm{Ni}$ and $\mathrm{Cd}$ were found near Dapeng Cove and Yaling Bay, while the maximum zone for As was in Fanhe Bay. All met-
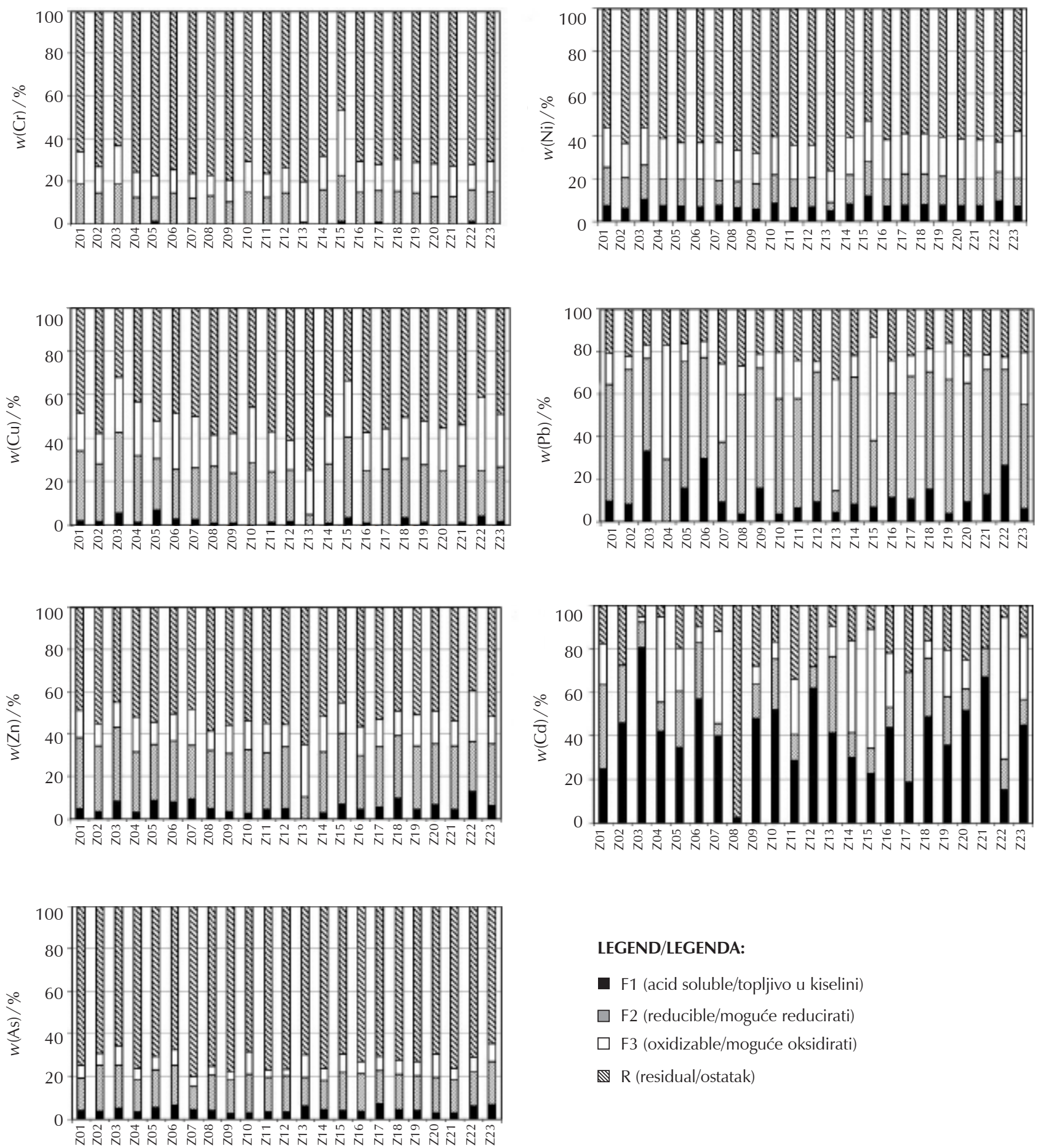

Fig. 3 - Distribution of heavy metals in different fractions in Daya Bay surface sediments Slika 3 - Raspodjela teških metala u frakcijama površinskog sedimenta u zaljevu Daya 
als reached a maximum value at Z05 located in an aquaculture area and near the densely polluted coastal region in Yaling Bay. The causes of the observed distribution are unknown. However, it is reasonable to propose that the human activity in the tested area contributed significantly to the enrichment of these metals in DYB. Other than three small rivers discharging into Dapeng Cove, there are no large rivers discharging into DYB. The organic matter content (TOC) in the Daya Bay surface sediments varied slightly with values ranging from $0.58 \%-1.10 \%$ and an average value of $0.78 \%$. The spatial distribution pattern of TOC was in accordance with the distribution of the selected metals tested.

\section{Heavy metal speciation distributions}

As shown in Fig. 3, Cr, Ni, Cu, Zn, As, and $\mathrm{Mn}$ and Fe were found associated mainly with the residual fraction $(\mathrm{R})$, while $\mathrm{Pb}$ was predominantly bound to reducible fraction (F2). In contrast, the majority of $\mathrm{Cd}$ was preferentially localized in the acid-soluble fraction (F1), indicating that this fraction was the main form for $\mathrm{Cd}$ to migrate from liquid to solid phase, which was in accordance with the result of Lin. ${ }^{3}$ The selected metals bound to exchangeable fractions in F1 through absorption to humus and clay minerals, which are sensitive to changes in the environment, can easily migrate and transform, and have high bioavailability and toxicity. The selected metals bound to carbonates in F1 through co-precipitation with carbonate minerals and are released easily under acidic conditions. The F2 fraction is the part of the metals wrapped by Fe/Mn oxide or hydroxide precipitation, which is difficult to release due to strong ionic bonding. In the F3 fraction, the selected metals are combined with organic matter reactive groups or generate water-insoluble material with sulphur ions, so they are not easily released under normal moderate reduction or a weak oxidizing environment. The metals bound to $\mathrm{R}$ fraction are mainly incorporated within the crystal lattices of silicates, and can only be released during weathering processes, so they are not considered bioavailable because the weathering process is much longer than the life period. ${ }^{11}$ Therefore, the ranking order of migration and transformation on the basis of the non-residual content of the metals was $\mathrm{Pb}>\mathrm{Cd}>\mathrm{Cu}>\mathrm{Zn}>\mathrm{Ni}>\mathrm{Cr}>$ As in Daya Bay surface sediments.

\section{Biological assessment}

It has been well established that the release of heavy metals and bioavailability are higher with the increasing percentage of the non-residual (F1 + F2 + F3) fractions of the sediments. ${ }^{12}$ In classical geochemistry, the primary and secondary phases are referred to as the primary minerals and the secondary metabolites in F1, F2 and F3 fractions, respectively. Since heavy metals from manmade pollution sources are in the secondary phase, the extent of heavy metal pollution in sediments could be evaluated with the ratio of secondary to primary phases $\left(K_{\mathrm{RSP}}\right)$. According to previous studies, $K_{\mathrm{RSP}}<1,1<K_{\mathrm{RSP}}<2,2<K_{\mathrm{RSP}}<3$, and $K_{\mathrm{RSP}}>3$, indicate no pollution, light pollution, moderate pollution, and heavy pollution, respectively. The $K_{\mathrm{RSP}}$ of the selected metals were in the following descending order: $\mathrm{Cd}>\mathrm{Pb}>\mathrm{Cu}>1>\mathrm{Zn}>\mathrm{Ni}>\mathrm{Cr}>$ As. The average $K_{\mathrm{RSP}}$ value of $\mathrm{Cd}$ was 9.34, while the average value of $K_{\mathrm{RSP}}$ for $\mathrm{Pb}$ was 4.93, suggesting that the studied sediments are heavily polluted with $\mathrm{Cd}$ and $\mathrm{Pb}$. The mean $K_{\mathrm{RSP}}$ values of $\mathrm{Cu}$ and $\mathrm{Zn}$ were 1.01 and 0.95 , respectively. However, the $K_{\mathrm{RSP}}$ values of $Z n$ were greater than 1 in eight sampling stations. These results indicate that the studied sediments are only slightly polluted with $\mathrm{Cu}$ and $\mathrm{Zn}$. The $K_{\mathrm{RSP}}$ values of $\mathrm{As}, \mathrm{Cr}$ and $\mathrm{Ni}$ were less than 1 , indicating that there was basically no pollution in this area for $\mathrm{As}, \mathrm{Cr}$ and $\mathrm{Ni}$.

\section{Correlations}

The correlation analysis was carried out to determine the relationships between the sediment characteristics (TOC, clay, Mz, Mn-F2 and Fe-F2) ${ }^{+}$and the extracted heavy metals of each fraction by IBM SPSS 19.0. As shown in Table 1 $\left({ }^{* *} p<0.01\right.$ and $\left.{ }^{*} p<0.05\right)$, the analysis results were as follows.

(1) The F2 and total fraction of $\mathrm{Cr}, \mathrm{Ni}$ and $\mathrm{Zn}$ were significantly correlated with TOC, Mn-F2, Fe-F2, clay and silt. For $\mathrm{Cr}$, the $\mathrm{F} 1$ fraction was correlated with clay and silt, and F3 with TOC. The $\mathrm{R}$ fraction showed positive correlation with TOC $(r=0.730, p<0.01)$, clay $(r=0.361, p<0.05)$ and silt, respectively. For $\mathrm{Ni}$, the F1 and F3 fraction showed significant correlation with TOC and silt, while R with TOC $(r=0.807, p<0.01)$, clay $(r=0.350, p<0.05)$ and silt $(r=0.510, p<0.05)$. Moreover, the F1 and F3 of $\mathrm{Zn}$ were correlated with silt and TOC separately, and R with TOC $(r=0.866, p<0.01)$, clay $(r=0.367, p<0.05)$ and silt $(r=0.512, p<0.05)$. So TOC, clay and silt mainly affected the distribution of $\mathrm{Cr}, \mathrm{Ni}$ and $\mathrm{Zn}$ because the main fraction of $\mathrm{Cr}, \mathrm{Ni}$ and $\mathrm{Zn}$ was $\mathrm{R}$ in this area.

(2) The total Cu was significantly correlated with TOC, Mn$\mathrm{F} 2$ and Fe-F2 at $p<0.01$. The F2 fraction was correlated with TOC, Mn-F2 and Fe-F2. The F3 and R fractions were correlated with TOC. In this area, the $\mathrm{R}$ fraction was the main speciation of $\mathrm{Cu}$, so $\mathrm{Cu}$ was mainly influenced by TOC. In addition, the main factors influencing As was also TOC.

(3) The F2 and total fraction of $\mathrm{Pb}$ were found significantly correlated with TOC, Mn-F2, Fe-F2 and silt. For the other three fractions, only the $\mathrm{Pb}$ in $\mathrm{R}$ fraction was correlated with TOC at $p<0.01$. Therefore, the main factors influencing $\mathrm{Pb}$ in DYB were Fe-F2, TOC, silt, Mn-F2 and clay because $\mathrm{Pb}$ was mainly bound to $\mathrm{F} 2$ fraction.

(4) For Cd, the total and F1 showed significant correlation with TOC, the correlation coefficients being 0.464 $(p<0.05)$. The $\mathrm{Cd}$ in residual fraction was correlated with TOC $(r=0.494, p<0.05)$, and silt $(r=0.497, p<0.05)$. Therefore, TOC mainly affected the distribution of $\mathrm{Cd}$ because the main fraction of $\mathrm{Cd}$ was $\mathrm{F} 1$ in this area.

\section{Principal Component Analysis (PCA)}

To analyse further the general characteristics of the sediments in the studied region, the multivariate Principal Component Analysis (PCA) were conducted. PCA analysis incorporates the seven metal concentration data of all

\footnotetext{
${ }^{+}$The data Mn-F2 and Fe-F2 refer to reference 10.
} 
Table 1 - Correlation between fractions and environmental factors

Tablica 1 - Korelacija između frakcija i okolišnih čimbenika

\begin{tabular}{|c|c|c|c|c|c|c|c|}
\hline $\begin{array}{l}\text { Total } \\
\text { Ukupno }\end{array}$ & $\begin{array}{c}\text { Cr-total } \\
\text { Ukupno Cr }\end{array}$ & $\begin{array}{c}\text { Ni-total } \\
\text { Ukupno Ni }\end{array}$ & $\begin{array}{c}\text { Cu-total } \\
\text { Ukupno Cu }\end{array}$ & $\begin{array}{c}\text { Pb-total } \\
\text { Ukupno } \mathrm{Pb}\end{array}$ & $\begin{array}{c}\text { Zn-total } \\
\text { Ukupno Zn }\end{array}$ & $\begin{array}{c}\text { Cd-total } \\
\text { Ukupno Cd }\end{array}$ & $\begin{array}{c}\text { As-total } \\
\text { Ukupno As }\end{array}$ \\
\hline TOC & $0.864^{* *}$ & $0.871^{* *}$ & $0.766^{* *}$ & $0.569 * *$ & $0.870^{* *}$ & 0.225 & $0.579 * *$ \\
\hline Mn-F2 & $0.782^{* *}$ & $0.870 * *$ & $0.682^{* *}$ & $0.363^{*}$ & $0.858 * *$ & 0.257 & $0.719 * *$ \\
\hline Fe-F2 & $0.823^{* *}$ & $0.918^{* *}$ & $0.629 * *$ & $0.440^{*}$ & $0.874^{* *}$ & 0.161 & 0.460 \\
\hline clay/glina & $0.375^{*}$ & $0.369 *$ & 0.145 & 0.327 & $0.360^{*}$ & -0.016 & -0.156 \\
\hline silt/mulj & $0.475^{*}$ & $0.567^{* *}$ & 0.339 & $0.387^{*}$ & $0.562^{* *}$ & 0.101 & 0.002 \\
\hline F1 & $\mathrm{Cr}-\mathrm{F} 1$ & $\mathrm{Ni}-\mathrm{F} 1$ & Cu-F1 & $\mathrm{Pb}-\mathrm{F} 1$ & Zn-F1 & Cd-F1 & As-F1 \\
\hline TOC & 0.242 & $0.864^{* *}$ & 0.238 & 0.171 & 0.192 & $0.464^{*}$ & $-0.352^{*}$ \\
\hline clay/glina & $0.434 *$ & 0.312 & 0.121 & 0.146 & 0.209 & 0.133 & $-0.364^{*}$ \\
\hline silt/mulj & $0.527^{* *}$ & $0.522^{*}$ & 0.172 & 0.177 & $0.373^{*}$ & 0.117 & $-0.369 *$ \\
\hline F2 & $\mathrm{Cr}-\mathrm{F} 2$ & $\mathrm{Ni}-\mathrm{F} 2$ & Cu-F2 & $\mathrm{Pb}-\mathrm{F} 2$ & Zn-F2 & $\mathrm{Cd}-\mathrm{F} 2$ & As-F2 \\
\hline TOC & $0.766^{* *}$ & $0.818^{* *}$ & $0.682^{* *}$ & $0.711^{* *}$ & $0.861^{* *}$ & 0.025 & $0.694^{* *}$ \\
\hline $\mathrm{Mn}-\mathrm{F} 2$ & $0.621^{* *}$ & $0.839 * *$ & $0.572^{* *}$ & $0.665^{* *}$ & $0.836^{* *}$ & 0.196 & $0.796^{* *}$ \\
\hline Fe-F2 & $0.740^{* *}$ & $0.933^{* *}$ & $0.564^{* *}$ & $0.768^{* *}$ & $0.880 * *$ & 0.094 & $0.587^{* *}$ \\
\hline clay/glina & $0.369 *$ & $0.356^{*}$ & 0.214 & $0.378^{*}$ & $0.391 *$ & -0.197 & 0.047 \\
\hline silt/mulj & $0.579 * *$ & $0.638^{* *}$ & 0.347 & $0.673^{* *}$ & $0.604^{* *}$ & -0.007 & 0.204 \\
\hline F3 & $\mathrm{Cr}-\mathrm{F} 3$ & $\mathrm{Ni}-\mathrm{F} 3$ & Cu-F3 & Pb-F3 & Zn-F3 & Cd-F3 & As-F3 \\
\hline TOC & $0.708^{* *}$ & $0.869 * *$ & $0.557^{* *}$ & 0.164 & $0.522^{*}$ & -0.216 & $0.435^{*}$ \\
\hline clay/glina & 0.136 & $0.362 *$ & 0.079 & 0.122 & 0.020 & -0.152 & -0.283 \\
\hline silt/mulj & 0.196 & $0.545^{* *}$ & 0.221 & -0.024 & 0.205 & -0.018 & -0.325 \\
\hline $\mathrm{R}$ & $\mathrm{Cr}-\mathrm{R}$ & $\mathrm{Ni}-\mathrm{R}$ & Cu-R & $\mathrm{Pb}-\mathrm{R}$ & $Z n-R$ & $\mathrm{Cd}-\mathrm{R}$ & As-R \\
\hline TOC & $0.730^{* *}$ & $0.807^{* *}$ & $0.855^{* *}$ & $0.625^{* *}$ & $0.866^{* *}$ & $0.494 *$ & $0.480^{*}$ \\
\hline clay/glina & $0.361^{*}$ & $0.350^{*}$ & 0.072 & 0.204 & $0.367^{*}$ & 0.161 & -0.116 \\
\hline silt/mulj & $0.417^{*}$ & $0.510^{*}$ & 0.335 & 0.341 & $0.512^{*}$ & $0.497^{*}$ & 0.054 \\
\hline
\end{tabular}

sampling stations and explores the possible similar distribution behaviour of metals. In our study, the two principal components (PCs) extracted together explained $71.10 \%$ (PC1: $48.58 \%$; PC2: $22.52 \%$ ) of the metal variance. The principal component analysis loading plot (Fig. 4) showed that these metals were classified into Group $1(\mathrm{Cr}, \mathrm{Ni}, \mathrm{Cu}$, $\mathrm{Pb}$ and $\mathrm{As}$ ) and Group 2 (Cd and $\mathrm{Zn}$ ) according to similarities in the behaviour and distribution of these metals in the sediments. Firstly, all five metals in group 1 were strongly associated with PC1 (positive loading). Notably, $\mathrm{Cu}, \mathrm{Cr}$, As and $\mathrm{Ni}$ were mainly present in $\mathrm{R}$ fraction, reflecting lithogenic origin. Thus, PC1 is supposed to reflect the contribution of natural geological sources of metals in the coastal sediments. With regard to Group 2, the PCA results showed that $\mathrm{Cd}$ and $\mathrm{Zn}$ diverged significantly and were mainly present in $\mathrm{F} 1$ and $\mathrm{R}$ fraction, respectively. The research results ${ }^{5,7}$ show that industrial wastewater often contains large amounts of metals. The Daya Bay includes a large area of farming land, and the contribution to the high proportion of $\mathrm{Cd}$ in $\mathrm{F} 1$ and $\mathrm{F} 2$ might mainly be related to cage culture activities (feeding fodder) and fishing boats. Therefore, PC2 might represent industrial wastewater and aquacultural activity factor.

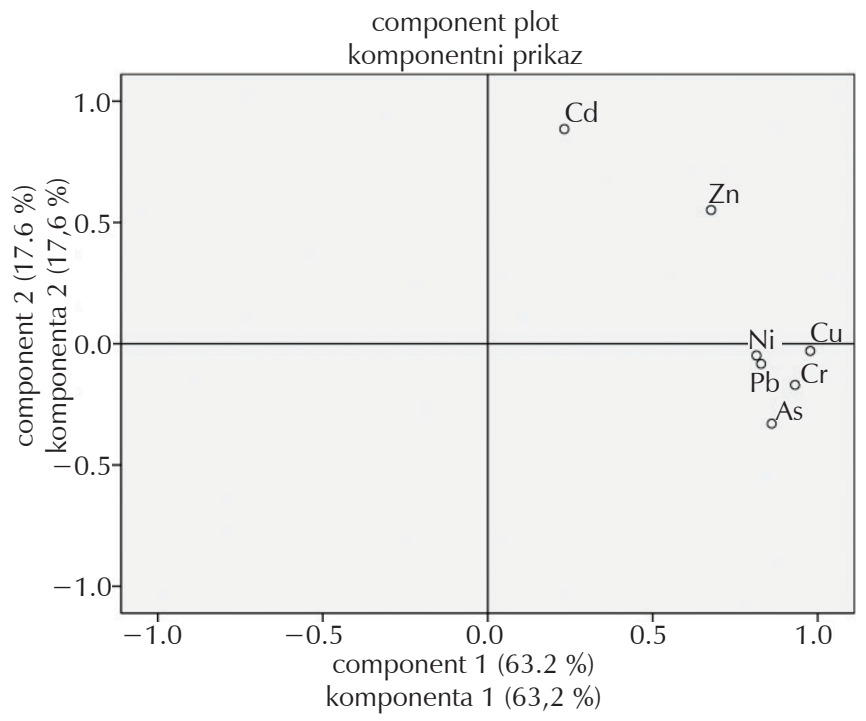

Fig. 4 - Principal component analysis loading plot of metallic elements

Slika 4 - Analiza glavnih komponenata učitavanja podataka metalnih elemenata 


\section{Conclusions}

In the present study, chemical analysis and speciation of $\mathrm{Cr}$, $\mathrm{Cu}, \mathrm{Ni}, \mathrm{Zn}, \mathrm{Pb}, \mathrm{As}$ and $\mathrm{Cd}$ between acid-soluble (F1), reducible (F2), oxidizable (F3) and residual (R) fractions were investigated in the contaminated sediments from the Daya Bay. The studied region has been negatively impacted by different anthropogenic activities as indicated by high contents of selected metals, such as $\mathrm{Cd}, \mathrm{Cu}, \mathrm{Pb}$ and $\mathrm{Zn}$. Furthermore, the combination of high concentrations of $\mathrm{Cd}$, $\mathrm{Cu}, \mathrm{Pb}$ and $\mathrm{Zn}$, and high percentage of association to the non-residual fraction (F1 + F2 + F3) has raised serious concerns in terms of the necessity for adequate strategies during dredging activities. TOC was the most important factor influencing the selected metals in Daya Bay as determined by the Pearson correlation analysis. The results of this study indicate the necessity of further studies for a better understanding of the feasibility of recovering different metals, and the technologies that can be applied in a cost-effective manner.

\section{Conflict of interest}

We have no conflict of interest to declare.

\section{ACKNOWLEDGEMENTS}

This work has been financed by the Ocean Public Welfare Scientific Research Project, State Oceanic Administration of the People's Republic of China (Grant No. 20110501506; No. 201105024).

\section{List of symbols and abbreviations Popis simbola i kratica}
DYB - Daya Bay
- zaljev Daya
BCR - Community Bureau of Reference
- Ured za standardizaciju Europske Zajednice
PCA - principal components analysis
- analiza glavnih komponenata
ICP-MS - inductively coupled plasma-mass spectrometry
- induktivno povezana spektrometrija plazma-masa
F1 - fraction 1 (acid soluble fraction)
- frakcija 1 (topljivo u kiselini)
F2 - fraction 2 (reducible fraction)
F3 - fraction 3 (oxidizable fraction)
- frakcija 3 (moguće oksidirati)
F4 $-\mathrm{R}$ (residual fraction)
- R (frakcija ostatka)
TOC - total organic carbon
- ukupni organski ugljik
GBW - offshore marine sediment
- morski sediment u blizini obale
$\begin{array}{ll}K_{\mathrm{RSP}} & \quad-\text { the ratio of secondary to primary phases } \\ & - \text { omjer sekundarnih i primarnih faza }\end{array}$

\section{References \\ Literatura}

1. L. L. Huang, X. M. Pu, J. F. Pan, B. Wang, Heavy metal pollution status in surface sediments of Swan Lake lagoon and Rongcheng Bay in the northern Yellow Sea, Chemosphere 93 (2013) 1957-1964, doi: http://dx.doi.org/10.1016/j. chemosphere.2013.06.080.

2. Y. E. Ma, Z. X. Ke, L. M. Huang, Y. H. Tan, Identification of human-induced perturbations in Daya Bay, China: Evidence from plankton size structure, Con. Shelf Res. 72 (2014) 1020, doi: http://dx.doi.org/10.1016/j.csr.2013.10.01‥

3. C. Lin, Y. Liu, W. Q Li, Speciation, distribution, and potential ecological risk assessment of heavy metals in Xiamen Bay surface sediment, Acta Oceanol. Sin. 33 (4) (2014) 13221, doi: http://dx.doi.org/10.1007/s13131-014-0453-2.

4. M. D. Subida, A. Berihuete, P. Drake, J. Blasco, Multivariate methods and artificial neural networks in the assessment of the response of infaunal assemblages to sediment metal contamination and organic enrichment, Sci. Total Environ. 22 (2013) 450-451, doi: http://dx.doi.org/10.1016/j.scitotenv.2013.02.009.

5. X. J. Yu, Y. Yan, W. X. Wang, The distribution and speciation of trace metals in surface sediments from the Pearl River Estuary and the Daya Bay, Southern China, Mar. Pollut. Bull. 60 (2010) 1364-1371, doi: http://dx.doi.org/10.1016/j.marpolbul.2010.05.012.

6. J. Yang, L. L. Cao, J. H. Wang, C. L. Liu, Speciation of Metals and Assessment of Contamination in Surface Sediments from Daya Bay, South China Sea, Sustainability 6 (12) (2014) 9096-9113, doi: http://dx.doi.org/10.3390/su6129096.

7. T. Marco, J. Delgado, S. Albanese, Heavy metals fractionation and multivariate statistical techniques to evaluate the environmental risk in soils of Huelva Township (SW Iberian Peninsula), J. Geochem. Explo. 119-120 (2012) 32-43, doi: http://dx.doi.org/10.1016/j.gexplo.2012.06.009.

8. G. Rauret, J. F. Lopez-Sanchez, A. Sahuquillo, R. Rubio, C. Davidson, A. Ure, Improvement of the BCR three step sequential extraction procedure prior to the certification of new sediment and soil reference materials, J. Environ. Monit. 1 (1999) 57-61, doi: http://dx.doi.org/10.1039/a807854h.

9. Z. B. Wang, S. Y. Yang, Z. X. Zhang, Comparison between two classic sediments classification method. Mar. Geo. Lett. (in Chinese) 3 (23) (2007) 36-40.

10. L. L. Cao, C. G. Huang, J. H. Wang, J. Xie, Pollution status of selected metals in surface sediments of the Pearl River Estuary and Daya Bay, South China Sea. J. Residu. Sci. Tech. 11 (4) (2014) 119-130.

11. N. F. Y. Tam, Y. S. Wong, Spatial variation of heavy metals in surface sediments of Hong Kong mangrove swamps, Environ. Pollut. 110 (2010) 195-205, doi: http://dx.doi.org/10.1016/ S0269-7491(99)00310-3.

12. F. C. Luis, O. E. Ramos, Fractionation of heavy metals and assessment of contamination of the sediments of Lake Titicaca, Environ. Monit. Assess 185 (2013) 9979-9994, doi: http:// dx.doi.org/10.1007/s10661-013-3306-0. 
SAŽETAK

\author{
Frakcioniranje toksičnih metala i polumetala \\ u sedimentima zaljeva Daya u Južnokineskom moru

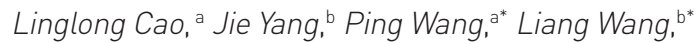 \\ Haitiao Tian, ${ }^{a}$ Mingkun Zou i Jian Xie a
}

Profili metala u sedimentima zaljeva Daya (DYB) u Kini određeni su sekvencijskom ekstrakcijom prema proceduri koju je izradio European Community Bureau of Reference. Da bi se odredili pokretljivost i biodostupnost otrovnih metala $(\mathrm{Cr}, \mathrm{Cu}, \mathrm{Ni}, \mathrm{Zn}, \mathrm{Pb}$ i $\mathrm{Cd})$ i polumetala (As), 2011. godine prikupljeni su i analizirani uzorci površinskog sedimenta s 23 reprezentativne lokacije. Pronađen je sljedeći redoslijed migracija, transformacija te stupnja zagađenja: $\mathrm{Pb}>\mathrm{Cd}>\mathrm{Cu}>\mathrm{Zn}>\mathrm{Ni}>\mathrm{Cr}>$ As. Smatra se da među tim elementima olovo predstavlja ozbiljnu prijetnju za ljudsko zdravlje i okoliš zbog znatnog udjela nerezidualnih oblika. Omjer primarne i sekundarne faze pokazuje da su proučavani sedimenti umjereno do jako onečišćeni bakrom i cinkom, također kadmijem i olovom. Povezanost varijabli (metala i polumetala) na svakom koraku uzastopnih ekstrakcija procijenjena je multivarijatnom analizom, uključujući i korelacijsku analizu i analizu glavnih komponenata. Zahvaljujući tim analizama, utvrđen je moguć izvor zagađenja. Korelacijska analiza pokazala je da je sadržaj ukupnog organskog ugljika najvažniji faktor koji utječe na raspodjelu otrovnih elemenata u zaljevu Daya. Analiza glavnih komponenata (PCA) pokazala je da proučavani elementi u području DYB-a potječu uglavnom od prirodnog trošenja stijena, potom i iz industrijskih otpadnih voda i otpadnih voda akvakulture.

\title{
Ključne riječi
}

Toksični elementi, frakcioniranje metala, sekvencijska ekstrakcija, procjena rizika, sediment, zaljev Daya

a South China Sea Marine Engineering and Environment Institute, SOA, 510300

Guangzhou Guangdong, Kina

b South China Sea Marine Environment

Monitoring Center, SOA, 510915

Guangzhou Guangdong, Kina

c Shanwei Marine Environment Monitoring

Center Station, SOA, 516600 Shanwei

Guangdong, Kina

Izvorni znanstveni rad Prispjelo 26. prosinca 2014. Prihvaćeno 13. travnja 2015. 